\title{
Social Modernization and the End of Ideology Debate: Patterns of Ideological Polarization ${ }^{1}$
}

\author{
Russell J. Dalton \\ University of California \\ 3151 Social Science Plaza \\ Irvine, CA 92697-5100 \\ Rdalton@uci.edu
}

April 2005

Prepared for the conference on "Beliefs, Norms and Values in Cross-national Surveys", University of Tokyo, Tokyo, Japan, December 2004.

1 I would like to thank Alix van Sickle for her assistance on work that led to the research presented here, Kamal Sadiq for our discussions about this research, and Ronald Inglehart for providing access to the World Values Survey data. 


\begin{abstract}
Over forty years ago, Daniel Bell made the provocative claim that ideological polarization was diminishing in Western democracies, but new ideologies were emerging and driving politics in developing nations. This article tests the End of Ideology thesis with a new wave of data from the World Values Survey (WVS) that covers over 70 nations representing more than 80 percent of the world's population. We find that polarization along the Left/Right dimension is substantially greater in the less affluent and less democratic societies than in advanced industrial democracies. The correlates of Left/Right orientations also vary systematically across regions. The twin pillars of economic and religious cleavages remain important in European states; cultural values and nationalism provide stronger bases of ideology in Asia and the Middle East. As Bell suggested, social modernization does seem to transform the extent and bases of ideological polarization within contemporary societies.
\end{abstract}




\section{Social Modernization and the End of Ideology Debate: Patterns of Ideological Polarization}

In the halcyon days of the early 1960s, Daniel Bell (1960) made a provocative claim about the "End of Ideology. Bell maintained that "In the Western world, therefore, there is a rough consensus among intellectuals on political issues: the acceptance of a Welfare

State; the desirability of decentralized power; a system of mixed economy and of political pluralism. In that sense, too, the ideological age has ended" (pg. 373). He also claimed that while ideological debates had been exhausted in the West, new ideologies were emerging and driving politics in Asia and Africa.

For more than a generation, the basic premise underlying Bell's claim has been widely debate. The apparent erosion of the class cleavage in Western democracies, and the emergence of a consensus in support of the welfare state were taken as indicators of the erosion of traditional ideological divisions (Kirchheimer 1966; Thomas 1979). By the 1990s, Mark Franklin and his colleagues (1992) argued that social group differences in voting patterns had sharply narrowed in Western democracies because these nations had successfully addressed the social divisions underlying these cleavages. Ideology had ended!

As the old cleavages apparently waned, however, new forms of political cleavage emerged in the advanced industrial democracies. This created a new debate over whether ideology was ending, or merely shifting the content of ideological competition. Most notably, Ronald Inglehart $(1977,1990)$ and others have argued that new types of postmaterial issues were repolarizing Western publics, stimulating new conflicts over environmental quality, gender equality, and life style choices. The rise of Green parties and other social movements injected new ideological debates in the politics of advanced industrial democracies. More recently, a New Right reaction to these issues has further polarized contemporary politics.

This debate has largely focused on Bell's claim about the End of Ideology in the West, but not his comparison between the developed and developing world. In fact, there has been little systematic research on how social modernization may have affected the bases of ideological cleavage as Bell suggested. Our paper takes a broad international 
view of the End of Ideology debate. The End of Ideology thesis argues that ideological differences will moderate as nations experience social modernization. This occurs because increasing affluence provides the resources to address some of the most pressing social needs that have long been a primary goal of government: providing economic sustenance and security. In addition, the increasing complexity of a developed industrial society leads to a more differentiated social structure, more complex patterns of social and economic relations, and more interactions between members of the polity. Black/white political differences might become muted into shades of grey by the complex structure of modern societies and cross-cutting interests. Indeed, this was implicit in much of the literature on the impact of modernization on political conflict.

We test the End of Ideology and Postmaterial hypotheses with a new wave of data from the World Values Survey (WVS). The fourth wave of the WVS includes an unprecedented set of nations spanning the six inhabited continents and representing the diverse cultural, political and economic variations across nations. Over 70 nations are available for analysis, and unequaled resource in the social sciences.

We develop our analyses in several steps. First, we discuss the argument and logic underlying the End of Ideology hypothesis, and the rival Postmaterial hypothesis. Second, we use cross-national aggregate data to test the core hypothesis of whether ideological positions are less polarized in advanced industrial democracies, while continuing to divide the publics in the developing world. Third, we examine the whether the correlates of ideology--and hence the meaning of ideological cleavage--vary systematically across nations. These empirical findings provide the basis for discussing the relationship between social modernization and ideology, and the likely consequences of this relationship for contemporary political systems.

\section{The End of Ideology Thesis}

Daniel Bell premised the End of Ideology Hypothesis on a set of social changes that were transforming Western democracies. One factor was the tremendous economic progress of the mid- $20^{\text {th }}$ century, and the concomitant transformation of the employment patterns and living conditions. In a later work, Bell (1973) articulated this position in more detail, forecasting the emergence of post-industrial societies as the end-product of this 
transformation. The development of the welfare state, expanding employment in the tertiary sector, increasing geographic and social mobility all contributed to the blurring of traditional ideological divisions. Similarly, scholars such as Lane (1965) and (Beer 1978) discussed how the "age of affluence" would lessen attention to the economic controversies of the past and lead to a new period of political consensus.

A second element of Bell's (1960) thesis was that modern societies were steadily becoming more secular. This trend was lessening the moral content of political debate. In addition, he argued that political ideologies had traditionally had to compete with religion for public support. As religious attachments moderated, so also could the emotional attachments to a political position. Religion remains an important element in many Western democracies, but its influence has waned as a consequence of social modernization (Norris and Inglehart 2004).

Moreover, in contrast to the West, Bell held that ideology continued to be a driving political force in developing nations. He concluded that "the extraordinary fact is that while the old nineteenth-century ideologies and intellectual debates have become exhausted [in the West], the rising states of Asia and Africa are fashioning new ideologies with a different appeal for their own people" (Bell 1960: 373). ${ }^{1} \mathrm{He}$ emphasized the importance of nationalism, ethnicity, Pan-Arabism, and other ideological conflicts in the developing world. In a recent update to his initial book, Bell (2000) stressed the role of ethnicity and nationalism as source of division in developing nations. At the same time, one might add that the struggles over economic well-being and individual rights still existed in the developing world, even if advanced industrial democracies had made substantial progress in addressing these concerns.

In contrast, the Postmaterial Hypothesis challenged the accuracy of the End of Ideology thesis as applied to advanced industrial societies. Ronald Inglehart (1977, 1984, 1990) agreed that the traditional bases of ideological cleavage were eroding, especially visible in the class cleavage and the economic values underlying this framework. Inglehart explicitly stated that there was a withering away of Marxian politics (1990: ch. 9). In Marx's place, however, new political controversies over life style issues, quality of life, and self-expression were emerging in postindustrial societies. This directly led to research on the changing content of "Left" and "Right" in these societies (Inglehart and 
Klingemann 1976; Inglehart 1984; Fuchs and Klingemann 1989; Knutsen 1995; Evans et al. 1996). For older citizens, these terms appear largely synonymous with socioeconomic polarization: Left means support for social programs, working-class interests and the influence of labor unions. Right is identified with limited government, middle-class interests, and the influence of the business sector. Among the young, however, postmaterial or libertarian issues provide a new basis of ideological identity. Left means opposition to nuclear energy, support for sexual equality, an internationalist orientation, or endorsement of multiculturalism. Right means a preference for traditional lifestyles, moral values, and a traditional sense of national identity and interest. Public opinion surveys from several Western democracies demonstrated the existence of these two separate dimensions of cleavage, and the generational patterns implied by the Postmaterial thesis (Inglehart 1984; Evans et al. 1996). In summary, the Postmaterial hypothesis holds that ideology did not end, but the content of ideology changed with social modernization.

A second critique of the End of Ideology hypothesis involves Bell's assumptions about the developing world. He wrote at a time when decolonialization and national independence movements were transforming the Third World. During this period, nationalism and independence were powerful symbols in these nations. Furthermore, the political ideologies of these regimes were often portrayed in stark terms because the superpowers used the developing world as a surrogate for direct competition. Thus, political elites often stressed communist or Western orientations. However, it was less clear whether these geopolitical choices motivated the thinking of the populace. And with the end of the Cold War, this polarization also quickly dissipated. Research also implied that these publics have limited ideological orientations and be relatively unengaged in politics (e.g., Almond and Verba 1963; Pye and Verba 1965). The limited empirical research on ideological orientations among Third World publics has not resolved these contrasting images (e.g., Nathan and Shi 1996; Mainwaring 1999; Shin and Jhee 2004). In short, the nature and content of ideological attachments among publics in the developing world is imprecisely understood.

We examine these rival theories using the data from the newest wave of the World Values Survey. We first test whether ideological extremism varies systematically 
with socio-economic characteristics of the nation. Does social modernization moderate political polarization? Second, we examine the correlates of Left/Right attitudes within nations to determine whether the content of ideological orientations also changes with social modernization.

\section{The World Values Survey}

The World Values Survey (WVS) is a worldwide investigation of sociocultural and political change. A network of social scientist at leading universities and research centers around world conducts the WVS. An international network of social scientists carries out this project, coordinated by a directorate board. The board develops the questions to include in the survey, and this is translated in the national language by each research institute. The WVS spans four waves since 1981.

This paper is largely based on data from the fourth wave of the WVS, which includes representative national surveys in more than 65 societies on all six inhabited continents. Virtually all the nations of Western and Eastern Europe are included, along with most other OECD democracies. The unusual feature of the fourth wave is the expansion of the project to a set of developing nations that were previously not included in international survey projects. The East Asian surveys, for example, include Vietnam, Singapore and Indonesia, as well as the more commonly surveyed nations of China, Japan, Korea and the Philippines. The WVS includes a new set of Arab nations, such as Iran, Jordan, Egypt and Morocco. There are additional surveys in several sub-Saharan nations and extensive surveying in Latin America. The data from the fourth wave, and in some additional nations surveyed in the third wave, have been released as a merged cross-national data file (Inglehart et al. 2004). ${ }^{2}$ The World Values Survey provides a unique resource to look at broad questions of social modernization and the comparison between developed and developing nations.

\section{Measuring Ideological Position}

Political scientists may disagree on the content and nature of ideological competition, but there is general agreement that some ideological framework or core political identity is used to organize political discourse in a nation and the individual belief systems of the 
citizens. Typically, such broad orientations are described in terms of Left/Right attitudes (Fuchs and Klingemann 1989; Barnes 1997). Political issues are discussed or summarized in terms of Left/Right or liberal/conservative philosophies, parties are summarized by their position along this continuum, and politicians are evaluated by their political tendencies. The ability to think of oneself in Left/Right terms does not imply that citizens possess a sophisticated conceptual framework or theoretical dogma. For many individuals, Left/Right attitudes are a summary of their positions on the political issues of greatest concern.

Survey data from developing nations is limited. However, Huber and Inglehart analyzed elite perceptions of political cleavages across 42 nations and concluded: "The left-right dimension, then, can be found almost wherever political parties exist, but it as an amorphous vessel whose meaning varies in systematic ways with the underlying political and economic conditions in a given society" (1995: 110).

The World Values Survey adopted the common question of asking respondents to position themselves along a 10-point scale, where 1 is labeled as Left and 10 is labeled as right:

In political matters, people talk of "the left" and "the right." How would you place your views on this scale, generally speaking?

$\begin{array}{llllllllll}1 & 2 & 3 & 4 & 5 & 6 & 7 & 8 & 9 & 10 \\ \text { Left } & & & & & & & & & \text { Right }\end{array}$

In some nations, the political discourse is different, and so alternate wording is used for the endpoints of the scale. ${ }^{3}$ We are less concerned with the labeling of the scale's poles, as long as these labels reflect the shorthand of political polarization in the nation. When there were deviations, the national teams made these decisions to produce maximum comparability to the theoretical construct. We will use the term "Left/Right" as a shorthand for this scale in the World Values Survey, although we recognize the exact terminology for this scale may vary in some nations.

This operationalization of ideology is certainly different from the more rigorous meaning embedded in Bell's writings. Mass publics typically lack the type of strict ideological reasoning that exists among political elites and intellectuals. Instead, we are 
tapping a framework of political thinking that is closer to Anthony Downs' (1957) conceptualization of Left/Right as a cognitive framework for orienting political debate and mass beliefs.

Some indication of the basic validity of such orientations comes from the large majorities of the public who can position themselves of this scale (see Table 1). Across the 75 nations in our analyses, roughly three-quarters of the public place themselves on this scale. This scale appears most problematic in the Arab and Middle Eastern nations. Relatively small proportions in Pakistan (12\%), Morocco (27\%), Jordan (36\%), Algeria (46\%), and Iran (59\%) locate themselves in Left/Right terms. The methodological appendix for the Jordanian survey, for instance, flags this as a problematic question in their survey. The terms "Left" and "Right" lack relevance in the Middle East, where political divisions certainly exist but are expressed using different terminology. In addition, the percent of the public that can locate themselves on the Left/Right scale tends to be lower in some of the new democracies of Eastern Europe where the lines of political competition are still forming. On the whole, however, most citizens in most nations can describe themselves in Left/Right terms.

$$
===\text { Table } 1 \text { goes about here }===
$$

\section{Cross-national Comparisons of Ideological Polarization}

The essence of the End of Ideology hypothesis is that social modernization moderates ideological polarization, providing a more centrist and moderate political debate. The tensions in advanced industrial societies are not between survival and starvation or between opposing moral absolutes, but between more modest differences in political means and ends. Thus, the most direct test of the hypothesis is to see if ideological polarization moderates with social and political development. ${ }^{4}$

We began our analysis by calculating the percentage in each nation that scored at either the two most Leftist categories on the ideological scale, or the two most Rightist categories on the scale. ${ }^{5}$ These percentages are based only on those who positioned themselves on the scale as an indicator of the politicized public. Figure 1 presents the relationship between national affluence (GNP per capita, adjusted for purchasing power parity) with Left and Right extremism. Clearly, there is a strong negative curvilinear 
relationship between extremism and affluence. For Left extremism, the relationship has a Multiple R of .50; for Right extremism the R is .56. Right extremism is especially high in less affluent nations, reaching over 20 percent in the poorest nations. Both Left and Right extremism average only about 5 percent of the public in the most affluent societies.

$$
==- \text { Figure } 1 \text { goes about here }===
$$

The nature of the political controversies certainly varies across these nations, so a Left extreme position likely taps a different subset of issues. Thus, we are not making claims about the content of these ideological positions at this point (although see our discussion below). Rather, we are asking if the polarization of mass publics is systematically related to economic development--and the empirical evidence answers with a strong "yes". Furthermore, it is not the case that the Left is polarized in one nation, and the Right in another. There is a significant positive relationship ( $r=.34)$ between the percentage of Left and Right extremists across nations. The cumulative nature of these patterns is even more evident if we combine Left and Right extremists together; the Multiple R with national income increases to .64. Thus, independent of the content of political controversy, citizens in lower income nations are more likely to divide themselves into sharply opposing ideological camps.

To make sure that these patterns were not unique to the World Values Survey because of the particular group of nations in the study or instrumentation effects, we replicated these analyses with data from the Comparative Study of Electoral Systems (CSES). Module I of the CSES surveyed 22 democracies and included a question on Left/Right self-placement. We calculated the percentage of the public that took the two extreme points on either the Left or Right end of the continuum. The percentage of extremists was strongly correlated (.68) with a measure of national affluence--virtually an identical result to the WVS.

A similar pattern occurs if we use an indicator of political development, measured by the Freedom House scores. There is a strong negative relationship between the percentage of extreme Leftists ( $\mathrm{R}=.49)$, extreme Rightists $(\mathrm{R}=.40)$, and total extremism $(\mathrm{R}=.52)$ in the World Values Survey. This common pattern should be expected since the GNP and Freedom House scores are themselves so strongly correlated ( $r=.73)$. 
Our findings thus broadly affirm Bell's thesis of the convergence of ideology with socio-political development. Similarly, Mainwaring (2005) has recently used data from the Comparative Study of Electoral Systems to show that the Left/Right polarization of party sympathizers is substantially weaker in more developed nations. In other words, less affluent and less democratic nations face an electorate that is often sharply polarized on the dominant ideological divisions of the nation. The centrifugal forces created by such polarization likely produce strains in governing, which may lessen the performance of the government and even weaken the stability of the regime. ${ }^{6}$ Thus regardless of the content of the ideological dimension, this debate is characterized by a sharply divided public in many developing nations.

Conversely, ideological polarization is more moderate in advanced industrial democracies. Far fewer individuals place themselves at the extreme positions on the Left/Right scale in these nations. This suggests that political competition is more manageable, because a large moderate center provides a middle ground for political discourse and cooperation. Even when elite debates may become intense between the ideological extremes, the lack of an equally polarized public moderates these controversies. Thus, while the centrifugal forces of polarization create political strains in many developing nations, a large moderate center exerts centripetal forces in most advanced industrial democracies.

\section{Social Modernization and the Content of Ideology}

The second element of the End of Ideology debate involves the potential shift in the content of ideology because of social modernization. Inglehart's Postmaterial thesis holds social modernization addresses many of the basic economic and sustenance needs that traditionally have been the major policy goals of citizens and their governments. In European political systems, these needs were typically expressed in Marxian class-based issues such as the nationalization of industry, redistribution of income, and the government's role in the economy. However, as these goals were addressed, public and

eventually government attention shifted attention toward a new set of postmaterial goals. Issues such as environmental protection, social equality, self-expression and life style choices typified this new postmaterial issue agenda. He demonstrated this pattern with 
data from Western Europe, which showed that Left/Right identities were a mix of traditional economic issues and postmaterial issues (Inglehart 1990: ch. 9). Moreover, the connection between Left/Right ideology and postmaterial issues was substantially stronger among the young, suggesting a generational shift in ideological orientations was occurring.

As we have noted above, the empirical evidence on the content of Left/Right orientations in developing nations is quite limited. In many of these nations we find that a high percentage of the public is able to place themselves on this scale. Our next task is to determine the content of these orientations by examining the correlates of Left and Right.

The World Values Survey includes three sets of issues that are broadly discussed in the literature on ideology.

Economic Orientations. The End of Ideology debate typically focuses on the question of whether social modernization lessens Marxist based ideological controversies. This theme is highly visible both in Bell's writings and in Inglehart's. We selected four measures from the WVS that seem to best represent this cleavage: ${ }^{7}$

- $\quad$ Government ownership of business and industrial should be increased

- $\quad$ Competition is good. It stimulates people to work hard and develop ideas

- $\quad$ People should take more responsibility to provide for themselves

- We need larger income differences as incentives for individual effort Some of these issues are linked to socialist debate about the relationship between government and the economy. Other questions focus on issues of inequality and individual responsibility that may have equal relevance in developing nations. Postmaterial Orientations. Inglehart's $(1977,1999)$ concept of postmaterial value change led us to select the following four items as tapping these orientations:

- $\quad$ Four-item postmaterial values index

- $\quad$ Sustenance vs Self-expressive values

- $\quad$ Support for environmental protection

- $\quad$ Support for gender equality 
Other Orientations. While much of the debate as focused on hypothesized transition from economic to postmaterial issues, the literature also discusses other potential basis of polarization. For instance, religion is regularly seen as stimulating moral issues that are separate from either economic or postmaterial orientations (Norris and Inglehart 2004; Huntington 1996). We also include support for democracy to see if regime form provides a basis of political cleavage in less-democratic nations (see Shin and Jhee 2004). Bell and others have claimed that nationalism may serves as a basis of political identity in developing nations. Therefore, we included four other measures into our analyses:

- Importance of God in one's life

- $\quad$ Consider oneself religious

- $\quad$ Democratic regime index

- $\quad$ National pride

We are not interested in the distribution of these issue opinions in each nation. Rather, we are asking to what extent these different issue dimensions are related to Left/Right orientations, signifying the content of Left/Right positions in the nation.

Because economic and political development tend to be strongly related, and we have a large number of nations, we group nations into six broad cultural regions to provide the broad perspective encapsulated in the End of Ideology debate. We identify six regions with common characteristics: advanced industrial democracies, the postcommunist nations of East Europe, Latin American nations, Asian democracies, Middle Eastern nations, and a diverse set of African nations. ${ }^{8}$

\section{Economic Orientations}

We first analyze the relationship between economic orientations and Left/Right selfplacement. The literature provides only partial evidence on what we might find across global regions. Inglehart demonstrated that economic issues are still significantly related to Left/Right orientations in Europe, even if postmaterial issues also are part of contemporary Left/Right divisions. Kitschelt and his colleagues (1999) also found that economic issues were often linked to Left/Right orientations among East European publics in the early 1990s. Both of these studies, however, are limited to a single geographic region, and the comparison to other regions is implicit. 
The top panel of Table 2 presents the relationship between four economic issues and Left/Right orientations across the six regions. The table presents the unstandardized regression coefficients for all the nations in a region pooled together. We used the unstandardized coefficients because the previous analyses demonstrated the substantial differences in Left/Right variance across regions.

$$
===\text { Table } 2 \text { goes about here }===
$$

Economic polarization along the Left/Right scale is strongest in the advanced industrial democracies. On the one hand, these controversies have been institutionalized in the structure of the party system and elite competition for more than a century, and this persisting importance is still apparent. Europe was, after all, the birthplace of Marxism, socialism and the ideological movements that generated the traditional meaning of Left. On the other hand, longitudinal evidence and generational comparisons suggest that economic controversies are moderating in Europe. ${ }^{9}$ A generation ago, economic polarization in Western Europe probably was even sharper.

Economic polarization also is a significant basis of political cleavage in East Europe. Certainly East Europeans were familiar with this ideological debate, since it was embedded in the communist political order. But this cleavage was blurred under the old regimes, since there was no ideological competition between alternative positions. The communist class structure also transformed the traditional class alignment; despite the claim that the regime represented the working class, the intelligentsia and middle class held a privileged status. However, after the transition to democracy, the traditional Left/Right economic alignment is emerging in East European party systems and is only slightly weaker than in the West (Kitschelt et al. 1999).

When one moves beyond Europe, however, economic controversies over the role of the state, income inequality, and market competition are relatively independent of Left/Right orientations. In Latin America, for instance, polarization on economic issues is barely linked to Left/Right attitudes. ${ }^{10}$ Economic polarization is also substantially weaker in Asian democracies, Arab nations and African nations. Marxism, and its attendant political controversies, may have structured political conflict in Europe, but such controversies are less central to the ideological framework of mass publics in the rest of the world. These results demonstrate that the socialist/capitalist controversies that 
structured politics in Europe, do not drive politics in the developing world. This does not preclude other economic issues from framing Left/Right attitudes among these publics, but we have not yet been able to systematically identify such economic issues using the WVS. However, it is clear that Left/Right divisions in the developing world are not strongly linked to the ideological conflicts over economic growth that structured European politics for the past century.

\section{Postmaterial Orientations}

Our theoretical expectation for postmaterial issues is quite clear. Since these issues supposedly enter the political agenda once socio-economic development addresses traditional economic and security concerns, postmaterial issues should be a significant source of ideological orientations only in advanced industrial democracies. Inglehart's $(1977,1990)$ analyses of postmaterial values support such a prediction.

The second panel of Table 2 presents the relationship between several postmaterial measures and Left/Right orientations. Rather than postmaterialism being the distinct basis of ideological polarization in advanced industrial democracies, these values are strongly related to ideology on a global scale. ${ }^{11}$ In most regions, postmaterialists are disproportionately Leftist, and this is the pattern in advanced industrial democracies, Latin America, Asian democracies, and Arab nations. Among these four regions, the relationship is actually weaker in the Western democracies. At the same time, postmaterialism has the opposite impact on ideology in Eastern Europe and Africa. In these two regions, materialists are more likely to locate themselves on the Right end of the scale. $^{12}$

One explanation for this apparent anomaly is that postmaterialism is related to broader value differences linked to modernization, which Inglehart and Welzel (2005) describe as the shift from survival to self-expressive values. These concerns are relevant beyond just advanced industrial democracies, and we might expect that survival concerns are even more salient in less affluent nations. To illustrate this broader relationship, the second row in this set of variables presents the relationship for self-expressive values. At the same time, it appears that historical conditions have created different linkages between these value orientations and Left/Right ideological labels. 
Another example of the postmaterial agenda is environmental protection. The WVS contained a number of environmental questions, and we selected an item on the willingness to pay more for environmental protection because it was included in the largest number of surveys. Environmentalism is significantly linked to Leftist orientations in the Western democracies $(b=.16)$, with weaker relationships in most other regions (and sometimes the relationship runs in the opposite direction). ${ }^{13}$ Thus, this postmaterialist issue does mobilize Western voters as Inglehart hypothesized.

Our final postmaterial example is support for gender equality. The emergence of a feminist movement in advanced industrial democracies is typically linked to the postmaterial agenda. However, Table 2 demonstrates that gender roles are commonly linked to Left/Right orientations even beyond the advanced industrial democracies. The strongest relationships are found in Arab nations, Asian democracies, and Latin America --regions where the role of women remains intensely debated (Inglehart and Norris 2003). Perhaps the greatest formal equality for women was achieved in Eastern Europe, and here gender role has the weakest link to ideological orientations.

In summary, these examples of postmaterial issues yield ambiguous regional patterns. As postmaterial issues, their impact should be strongest in advanced industrial democracies, where their impact is actually quite modest. ${ }^{14}$ Instead, these issues have a stronger impact in developing nations where questions of material well-being and gender roles are salient to many citizens. It may be that these issues are more visible in advanced industrial democracies, because in these nations the two sides are relatively balanced. However, where differences in opinion exist in these other regions, it serves as a basis of polarization. The other anomaly is Eastern Europe. The communist heritage of these nations has apparently created a different Left/Right alignment on these issues, with the Left becoming the advocate for materialist interests. The semantics of Left and Right have different meanings to post-communist electorates, and these meanings also likely vary across nations within the region (Kitschelt et al. 1999: 282-288).

\section{Other Orientations}

Bell suggested that factors such as decolonialization, nation-building, religion and ethnicity might provide the basis of Left/Right orientations in the developing world, as 
these nations faced different political problems than those that shaped the history of European societies. Therefore, we selected a set of measures from the World Values Survey that might tap such orientations. These analyses are even more tentative than the two prior sections, because research on the ideological orientations of publics in developing nations is much less extensive. Nevertheless, our exploratory analyses can help chart this territory and increase understanding of the nature of political cleavages in the developing world.

Several studies have demonstrated that religion is strongly related to Left/Right orientations in less developed societies (Norris and Inglehart 2004: ch. 9; Mainwaring 1999). However, it is difficult to study religious attachments in a comparable manner around the globe. The number of religious denominations across these 70+ nations confounds the broad comparisons we are seeking, and the patterns of religious observance are equally varied. The typical frequency of attendance at religious ceremonies varies widely across religions. Even monotheistic beliefs are not universal. Therefore, we relied on two questions to tap religious orientations. The first question asked about the importance of God in the respondent's life. The second asked whether the respondent considered himself/herself a religious person regardless of whether he/she went to formal religious services.

The last panel of Table 2 shows that religious attachments are related to Left/Right orientations in most regions. In Latin America and Asian democracies, both religious items are strongly related to Left/Right self-placements. In the former, it undoubtedly reflects the role of the Catholic Church in Latin American politics. The "importance of God" item has its strongest relationship in Arab nations ( $b=.206)$, roughly doubling this variable's impact in Western or Eastern Europe. Africa is the one region where neither religious question displays a substantively large coefficient. On a global scale, however, religion does matter, and its seems to matter more in the developing nations of Latin America, Asia and the Middle East.

Another potential ideological division involves orientations toward various aspects of nation building. We first compare whether support for a democratic regime structures Left/Right orientations. ${ }^{15}$ There is a clear interaction of ideology and national history. In post-communist East Europe, for example, the democratic orientations of the 
citizenry are linked to Rightist orientations because of the communist legacy. Similarly, in Arab nations the Left is tied to anti-Western and anti-democratic views, and democratic values lead to Rightist orientations. In Latin America and Asia the effects of democratic values is even stronger, and these orientations lead to Leftism. In short, regime choice is part of the ideological structure in new democracies and non-democratic nations, but the nature of this relationship varies with the historical alignment of Left/Right forces.

Our final measure taps nation building on a different level. The WVS asked about feelings of national pride, which we interpret as tapping nationalist orientations. National pride typically is related to Rightist orientations, except in Eastern Europe and Arab nations. We suspect that this reflect domestic political alignments similar to those displayed for democratic values.

These findings suggest that citizens in developing nations are more likely to orient themselves to politics in terms of religion or national identity issues, which generally outweigh economic issues as a basis of Left/Right identity. We suspect that ethnicity may also play a greater role in shaping political identities in developing nations (Elkins and Sides 2004; Bell 2000). The different bases of political identities in developing nations can also explain why politics may become so divisive and polarizing. While policy differences over economics or even environmental quality are more susceptible to compromise, divisions over religion, regime and political community are more fundamental, almost inviolable to their adherents.

\section{Combining Dimensions}

One advantage of the Left/Right scale is that it provides a summary of the issues of contention in a political system. However, our analyses show that Left/Right orientations do not derive from a single source, but reflect multiple dimensions. Even in the broad regional patterns we have presented, both economic and cultural factors shape political identities, and the mix of dimensions reflects both the social development of the nation, and its cultural/political history.

Therefore, the last step in our analyses combines the several dimensions to examine their joint and independent influence in forming Left/Right orientations. We 
selected a subset of six items from Table 2 to avoid multicollinearity among items tapping a similar concept. We began with the item on government ownership of business to measure the classic socialist/capitalist divide. As we have shown, this continues to shape the identities of some citizens. We selected support for the environment to tap potential postmaterial concerns. Although the gender role scale was initially analyzed to measure postmaterial orientations, based on the patterns in Table 2 we included it as a measure of traditional values in many developing nations (and thus distinct from postmaterial concerns). Belief in the importance of God provides a measure of religiosity. Support for democratic values is one element of political development that may be important in democratizing nations (e.g., Shin and Jhee 2004). National pride provides an indicator of how nationalism may shape Left/Right orientations. We included all six predictors in an OLS regression model, including all nations within each cultural region in separate analyses (Table 3). We consider these analyses as a preliminary attempt to map broad ideological orientations in terms of global regions, with the expectation that further research should probe these patterns on a nation-by-nation basis and with additional predictors.

$$
===\text { Table } 3 \text { goes about here }===
$$

Our findings for the advanced industrial societies are very consistent with previous research. In these nations, the two strongest correlates of Left/Right orientations are economics ( $(=.143$ ) and religion ( $(=.138$ ). These have been the two major pillars of social and political competition in Europe and other Western democracies, and their impact remains to the present. In addition, the postmaterial issue of environmental protection has greater weight in shaping the identities of these publics, relative to the other five regions in our analyses. Thus, the content of Left/Right identities remains quite full and rich in Western democracies, even if the intensity of these sentiments have moderate during the later half of the $20^{\text {th }}$ century.

East European publics generally mirror the pattern among Western publics. Economics and religion are the strongest correlates of Left/Attitudes in the East, albeit with significantly weaker coefficients in both instances. With our single cross-sectional survey we cannot tell whether the impact of these correlates is changing with democratization, and this is important in interpreting the present results. But indirect 
evidence suggests that ideological polarization is increasing along these cleavage lines. It is also significant that democratic values do not divide these publics. Immediately following the democratic transition, this may have been an important factor in structuring party competition and charting the institutional structure of the new system (Kitschelt et al. 1999). This division is no longer linked to Left/Right identities, however.

Consistent with our earlier analyses, people in developing nations are more likely to base their political identity on gender and religion. Gender and religion tap traditional value orientations based on the social patterns of pre-industrial societies. The importance of gender roles in shaping political identities in Latin America, the Middle East and East Asian democracies is a striking example of the persistence of these value cleavages. Orientations toward gender appear to tap feelings of equality between the sexes, as well as elements of tolerance and modernization that transcend the specific relationship between men and women (Inglehart and Norris 2003). Religion also displays a significant relationship with Left/Right orientations in Latin America and the Middle East. The nature of Eastern religion lessens its role as a political cleavage in East Asian democracies.

Perhaps what is the most striking in Africa is the narrow base of Left/Right orientations. The poverty of these nations precludes the strong class alignments as observed in European democracies as a consequence of industrialization. Neither religion nor gender roles taps into traditional value cleavages. The only substantial predictor of Left/Right is attitudes toward environmental protection; but this relationship runs in the opposite direction as in the advanced industrial democracies. We suspect that this question taps economic concerns (because of its reference to taxes in the question) rather than environmental quality per se. The other potential predictors of Left/Right orientations display only weak effects.

\section{Social Modernization and Ideology}

Does social modernization transform the ideological basis of mass belief systems? Daniel Bell $(1960,1973)$ offered a broad theoretical model of how social modernization would affect mass beliefs. First, Bell presumed that the degree of ideological polarization was narrowing in advanced industrial societies. Second, he claimed that the sources of 
ideological polarization also changed as a consequence of modernization. We have used the unprecedented resources of the World Values Survey to empirically examine Bell's theory to an extent never before possible.

We have painted on a large canvas, and used broad brush strokes. Before discussing our findings and implications, we want to stress the need for more extensive and detailed analyses across individual nations and using different issue dimensions. We examined a broad theory of social change, analyzing patterns of Left/Right polarization across six regions of the globe. Some of the specific national patterns within these regions undoubtedly vary from the overall pattern, and these national differences can provide insights into how national histories structure the framework of political competition. ${ }^{16}$ And it would be valuable to build upon our findings with other methodologies, such as open-ended inquiries into the meaning of "Left" and "Right." Thus, our findings provide an outline of the impact of social modernization on ideology that can be refined with more detailed analyses.

We treat the Left/Right attitudes of mass publics as an indicator of the ideological orientations that Bell described. In large measure, the degree of ideological polarization fits Bell's predictions. Polarization along the Left/Right dimension is substantially greater in the less affluent and less democratic societies than in advanced industrial democracies. Left and Right extremism reaches over 20 percent in the least developed nations, but averages only about 5 percent among the public in Western democracies.

The extent of political polarization is important because it can shape the political process of a nation. A long theoretical tradition holds that the centrifugal forces generated by polarization strain the political consensus (Sartori 1976: 131-173; Mainwaring 1999: 131-135). Bingham Powell (1982) for instance, demonstrated that support for extremist parties in a nation was a significant predictor of political violence. Similarly, Dalton and van Sickle (2004) found a significant relationship between the percentage of Left and Right extremists in a nation and the level of political protest. Just as the End of Ideology hypothesis linked ideological convergence to the moderation of political conflict, divided publics may strain the political order and the ability of states to govern.

Another major finding is that the correlates of Left/Right orientations vary systematically across regions. The twin pillars of economic and religious cleavages 
remain important in European states. These two bases of polarization are strongest in Western democracies ( $\beta=.143$ and $\beta=.138$ respectively), which runs counter both to Bell's End of Ideology hypothesis and Inglehart's Postmaterial hypothesis. We suspect that a century of partisan competition on these two cleavages generated even sharper differences in the mid- $20^{\text {th }}$ century, which remain apparent in our contemporary data. In other words, polarization was presumably even greater a generation ago (Kirchheimer 1966; Inglehart 1977, 1999). In addition, environmental issues have their greatest weight in Western democracies, suggesting that this new basis of cleavage is developing within the advanced industrial democracies.

In contrast, Left/Right orientations in other regions are typically not linked to the economic issues that divide European publics. In our set of Asian democracies, traditional social values (represented by attitudes toward gender roles) and political community (national pride) divide these publics. Thus, the social dimensions of class and religion that structure Western political systems are largely muted in the East, and postmaterial issues are also less salient.

Few among Arab publics express a Left/Right identity, since this nomenclature is not commonly used in political discourse. Where such Left/Right identities do exist, they are strongly related to attitudes toward gender roles. We see this as partially a reflection of the strong gender divide in Arab societies, as well as broader feelings of tolerance and acceptance of diversity that are tapped by the gender question (Inglehart and Norris 2004). Finally, African publics appear to have diffuse Left/Right orientations, we with relationships with all the correlates we examined.

In his recent comment on the End of Ideology, Bell (2000) claims that ethnicity and linguistic cleavages are strengthening in the developing world, providing a new basis of division--even if these divisions are not fully expressed in a broader worldview or ideology. The differing bases of ideology may explain why developing societies are so polarized, because political orientations are shaped by deeply-seated questions of moral and national identity. This pattern also suggests that these divisions will be more difficult to manage than the economic competition in advanced industrial democracies.

This evidence on the correlates of ideological polarization is important at several levels. Ideological frameworks broadly define the content of politics and the nature of 
political competition. If politics is framed in terms of a socialist/capitalist or a nationalist ideology, this will influence the policy choices presented to the public and the nature of political discourse. The dominance of one ideological framework can also exclude other issues from the agenda, as when the New Deal debate in America excluded race from consideration. Or, when nationalism issues submerge discussions of class interests. Thus, the ideological structures we described are important in modeling processes of coalition formation, political representation, and electoral competition.

In summary, it is premature to argue that ideology is ending in any region of the globe. Citizens in affluent and less-affluent societies still rely on broad orientations such as Left/Right identities as heuristics for political action. But social modernization does transform the content of ideological polarization and the degree of this division. Indeed, one of the major underdiscussed consequences of social modernization may be this transformation of the ideological debate and all that this implies. 


\section{References}

Almond, Gabriel and Sidney Verba. 1963. The Civic Culture. Princeton: Princeton University Press.

Barnes, Samuel. 1997. Electoral behavior and comparative politics. In Mark Lichbach and Alan Zuckerman, eds. Comparative Politics. New York: Cambridge University Press.

Beer, Samuel. 1978. The British Political System. New York: Random House.

Bell, Daniel. 1960. The End of Ideology: On the Exhaustion of Political Ideas in the Fifties. Glencoe, IL: Free Press.

Bell, Daniel. 1973. The Coming of Post-industrial Society. New York: Basic Books.

Bell, Daniel. 2000. The resumption of history in the new century. In The End of Ideology. Cambridge: Harvard University Press.

Dalton, Russell and Alix van Sickle. 2004. Who protests? The resource, institutional and cultural bases of protest. Paper presented at the annual meetings of the American Political Science Association, Chicago.

Downs, Anthony. 1957. An Economic Theory of Democracy. New York: Wiley.

Elkins, Zachary, and John Sides. 2004. In search of the unified nation-state: National attachment among distinctive citizens. Paper presented at the annual meetings of the Midwest Political Science Association.

Evans, Geoffrey, Anthony Heath and M. Lalljee. 1996. Measuring Left-Right and LibertarianAuthoritarian values in the British electorate. British Journal of Sociology 47: 93-112.

Franklin, Mark, Tom Mackie, and Henry Valen, eds. 1992. Electoral Change. New York: Cambridge University Press.

Fuchs, Dieter, and Hans-Dieter Klingemann. 1989. The Left-Right schema. In M. K. Jennings and J. van Deth, eds. Continuities in Political Action. Berlin: deGruyter.

Huber, John and Ronald Inglehart. 1995. Expert interpretations of party space and party locations in 42 societies, Party Politics 1: 73-111.

Huntington, Samuel. 1996. The Clash of Civilizations and the Remaking of World Order. New York: Simon \& Schuster.

Inglehart, Ronald. 1977. The Silent Revolution. Princeton: Princeton University Press.

Inglehart, Ronald. 1990. Culture Shift in Advanced Industrial Society. Princeton: Princeton University Press.

Inglehart, Ronald and Hans-Dieter Klingemann. 1976. Party identification, ideological preference and the Left-Right dimension among Western publics. In Ian Budge, Ivor Crewe and Dennis Farlie, eds., Party Identification and Beyond. London and New York: Wiley. 
Inglehart, Ronald and Pippa Norris. 2003. A Rising Tide: Gender Equality and Cultural Change around the World. New York: Cambridge University Press.

Inglehart, Ronald, et al. 2004. Human Beliefs and Values: A Cross-cultural Sourcebook Based on the 1999-2002 Values Surveys. Mexico City: Siglo XXI Editores.

Kirchheimer, Otto 1966. The transformation of the Western European party systems. In Joseph LaPalombara and Myron Weiner, eds., Political Parties and Political Development. Princeton: Princeton University Press.

Kitschelt, Herbert, et al. 1999. Post-communist Party Systems: Competition, Representation, and Inter-party Cooperation. New York: Cambridge University Press.

Knutsen, Oddbjørn. 1995. Left-Right materialist value orientations. In Jan van Deth and Elinor Scarbrough, eds. The Impact of Values. Oxford: Oxford University Press.

Lane, Robert. 1965. The politics of consensus in an age of affluence. American Political Science Review 59: 874-895.

Mainwaring, Scott. 1999. Rethinking Party Systems in the Third Wave of Democratization: The Case of Brazil. Palo Alto, CA: Stanford University Press.

Mainwaring, Scott. Forthcoming. Party system institutionalization and party system theory after the Third Wave of democratization. In Richard Katz, ed. Handbook of Political Parties. Oxford: Oxford University Press.

Nathan, Andrew and Tianjin Shi. 1996. Left and Right with communist characters: Issues and Alignments in Deng Xiaoping's China. World Politics 48: 522-550.

Norris, Pippa and Ronald Inglehart. 2004. Sacred and Secular: Religion and Politics Worldwide. New York: Cambridge University Press.

Powell, G. Bingham. 1982. Contemporary Democracies. Cambridge, MA: Harvard University Press.

Pye, Lucian, and Sidney Verba. 1965. Political Culture and Political Development. Princeton: Princeton University Press.

Sartori, Giovanni. 1976. Parties and Party Systems: A Framework for Analysis. New York: Cambridge University Press.

Shin, Doh Chull and Byong-Kuen Jhee. 2004. How does democratic regime change affect mass political ideology. Columbia, MO: University of Missouri.

Thomas, John. 1979. The changing nature of partisan divisions in the West: trends in domestic policy orientations in ten party systems. European Journal of Political Research, 7: 397413. 
Table 1. Percent of Public Placing Selves on Left/Right Scale

\begin{tabular}{|c|c|c|c|}
\hline Nation & Place Self & $\underline{\text { Nation }}$ & Place Self \\
\hline South Korea & 99 & El Salvador & 80 \\
\hline Malta & 97 & Georgia & 80 \\
\hline Nigeria & 97 & Switzerland & 80 \\
\hline Norway & 97 & Armenia & 79 \\
\hline Taiwan & 97 & Italy & 79 \\
\hline Dominican Rep. & 96 & Poland & 78 \\
\hline Netherlands & 96 & Spain & 78 \\
\hline Philippines & 96 & Bangladesh & 77 \\
\hline Sweden & 96 & Hungary & 77 \\
\hline Vietnam & 96 & Macedonia & 77 \\
\hline Albania & 95 & Portugal & 77 \\
\hline United States & 95 & Croatia & 76 \\
\hline Israel & 93 & Japan & 75 \\
\hline Turkey & 93 & Luxembourg & 74 \\
\hline Czech Rep. & 92 & Slovenia & 72 \\
\hline Iceland & 91 & New Zealand & 70 \\
\hline Uruguay & 91 & Estonia & 69 \\
\hline Denmark & 90 & Serbia & 69 \\
\hline South Africa & 90 & Tanzania & 69 \\
\hline Australia & 88 & Argentina & 68 \\
\hline Brazil & 88 & Azerbaijan & 67 \\
\hline Finland & 88 & Bulgaria & 67 \\
\hline Greece & 88 & Latvia & 67 \\
\hline Bosnia & 87 & Mexico & 67 \\
\hline Peru & 87 & Moldova & 67 \\
\hline Canada & 86 & Montenegro & 67 \\
\hline Uganda & 85 & Russia & 64 \\
\hline Chile & 84 & Ukraine & 63 \\
\hline Slovakia & 84 & Lithuania & 62 \\
\hline France & 83 & Iran & 59 \\
\hline Germany & 83 & Romania & 55 \\
\hline Belgium & 82 & India & 54 \\
\hline Indonesia & 82 & Belarus & 52 \\
\hline Ireland & 82 & Algeria & 46 \\
\hline Venezuela & 82 & Columbia & 46 \\
\hline Austria & 81 & Jordan & 36 \\
\hline Great Britain & 81 & Morocco & 27 \\
\hline Zimbabwe & 81 & Pakistan & 12 \\
\hline
\end{tabular}

Source: World Values Survey, waves 3 and 4 (Inglehart et al. 2004).

Note: These sample estimates normally have a confidence interval of $+/-3-5$ percent. So the percentage estimates for each nation should be interpreted considering this interval. 
Table 2 The Correlates of Left/Right Orientations

$\begin{array}{lcccccc}\text { Issues } & \text { West } & \begin{array}{c}\text { East } \\ \text { Europe }\end{array} & \begin{array}{c}\text { Latin } \\ \text { Amer }\end{array} & \begin{array}{l}\text { Asian } \\ \text { Democ. }\end{array} & \text { Arab } & \text { African } \\ \text { Economic Issues } & & & & & & \\ \quad \text { Government ownership } & .15 & .10 & -.02 & -.02 & -.01 & -.07 \\ \text { Competition is good } & .12 & .05 & .01 & .01 & .10 & -.08 \\ \text { Individual responsibility } & .10 & .08 & .03 & .07 & .04 & -.01 \\ \text { Accept income inequality } & .12 & .10 & .04 & .05 & .14 & .01 \\ \quad \text { Multiple R } & .26 & .19 & .07 & .11 & .17 & .10\end{array}$

Postmaterial Issues

$\begin{array}{lrrrrrr}\text { Postmaterial values index } & -.37 & .25 & -.37 & -.51 & -.48 & .06 \\ \text { Self-expressive values } & -.15 & .21 & -.14 & -.26 & \text { na } & .39 \\ \text { Environmental support } & -.16 & .14 & .00 & .09 & .09 & .32 \\ \text { Gender equality index } & -.22 & .03 & -.39 & -.63 & -.97 & -.17 \\ \quad \text { Multiple R } & .14 & .08 & .13 & .20 & .21 & .12\end{array}$

Other Issues

$\begin{array}{lrrrrrr}\text { Importance of God } & .10 & .07 & .17 & .13 & .19 & -.02 \\ \text { Consider self religious } & .53 & .35 & .44 & .65 & .09 & -.18 \\ \text { Democratic values } & -.33 & .27 & -.56 & -.55 & .33 & -.34 \\ \text { National pride } & .29 & .07 & .32 & .56 & -.07 & .34\end{array}$

$\begin{array}{lllllll}\text { Number of nations } & 26 & 23 & 10 & 6 & 6 & 5\end{array}$

Source: World Values Survey

Note: Table entries are unstandardized regression coefficients from simple bivariate regressions; the Multiple $\mathrm{R}$ is from a separate multivariate regression. We do not display the standard error for each coefficient, but they are presented in the multivariate regression model of Table 3. 
Table 3. A Multivariate Model of Left/Right Orientations across Regions.

\begin{tabular}{|c|c|c|c|c|c|c|c|c|c|c|c|c|}
\hline \multirow[b]{2}{*}{ Predictor } & \multicolumn{2}{|c|}{ West Dem. } & \multicolumn{2}{|c|}{ East Europe } & \multicolumn{2}{|c|}{ Latin Amer } & \multicolumn{2}{|c|}{ Asian Dem. } & \multicolumn{2}{|c|}{ Arab } & \multicolumn{2}{|c|}{ African } \\
\hline & $\mathrm{b}$ & $\beta$ & $\mathrm{b}$ & $\beta$ & $\mathrm{b}$ & $\beta$ & $\mathrm{b}$ & $\beta$ & $\mathrm{b}$ & $\beta$ & $\mathrm{b}$ & $\beta$ \\
\hline $\begin{array}{l}\text { Government } \\
\text { ownership }\end{array}$ & $\begin{array}{l}.105 \\
(.004)\end{array}$ & .143 & $\begin{array}{l}.098 \\
(.006)\end{array}$ & .114 & $\begin{array}{l}-.027 \\
(.008)\end{array}$ & -.030 & $\begin{array}{l}.052 \\
(.010)\end{array}$ & .068 & $\begin{array}{l}-.064 \\
(.028)\end{array}$ & -.068 & $\begin{array}{l}-.006 \\
(.013)\end{array}$ & -.007 \\
\hline $\begin{array}{l}\text { Environmental } \\
\text { protection }\end{array}$ & $\begin{array}{l}-.145 \\
(.014)\end{array}$ & -.064 & $\begin{array}{l}.116 \\
(.020)\end{array}$ & .044 & $\begin{array}{l}-.066 \\
(.029)\end{array}$ & -.023 & $\begin{array}{l}.063 \\
(.039)\end{array}$ & .021 & $\begin{array}{l}.092 \\
(.123)\end{array}$ & .023 & $\begin{array}{l}.309 \\
(.042)\end{array}$ & .104 \\
\hline $\begin{array}{l}\text { Gender } \\
\text { roles }\end{array}$ & $\begin{array}{l}.123 \\
(.018)\end{array}$ & .043 & $\begin{array}{l}-.031 \\
(.026)\end{array}$ & -.009 & $\begin{array}{l}.336 \\
(.038)\end{array}$ & .088 & $\begin{array}{l}.486 \\
(.050)\end{array}$ & .129 & $\begin{array}{l}.985 \\
(.153)\end{array}$ & .190 & $\begin{array}{l}.180 \\
(.058)\end{array}$ & .044 \\
\hline $\begin{array}{l}\text { Importance of } \\
\text { God }\end{array}$ & $\begin{array}{l}.085 \\
(.004)\end{array}$ & .138 & $\begin{array}{l}.075 \\
(.005)\end{array}$ & .107 & $\begin{array}{l}.139 \\
(.013)\end{array}$ & .105 & $\begin{array}{l}.049 \\
(.013)\end{array}$ & .056 & $\begin{array}{l}.206 \\
(.081)\end{array}$ & .075 & $\begin{array}{l}-.052 \\
(.026)\end{array}$ & -.029 \\
\hline $\begin{array}{l}\text { Democratic } \\
\text { values }\end{array}$ & $\begin{array}{l}-.287 \\
(.023)\end{array}$ & -.077 & $\begin{array}{l}-.269 \\
(.034)\end{array}$ & -.058 & $\begin{array}{l}-.445 \\
(.047)\end{array}$ & -.059 & $\begin{array}{l}-.260 \\
(.061)\end{array}$ & -.058 & $\begin{array}{l}.286 \\
(.144)\end{array}$ & .058 & $\begin{array}{l}.277 \\
(.065)\end{array}$ & .061 \\
\hline National pride & $\begin{array}{l}.210 \\
(.016)\end{array}$ & .081 & $\begin{array}{l}.027 \\
(.020)\end{array}$ & .011 & $\begin{array}{l}.238 \\
(.043)\end{array}$ & .056 & $\begin{array}{l}.374 \\
(.041)\end{array}$ & .129 & $\begin{array}{l}.188 \\
(.163)\end{array}$ & .034 & $\begin{array}{l}.296 \\
(.060)\end{array}$ & .070 \\
\hline Constant & 6.096 & & 5.156 & & 5.740 & & 6.117 & & 1.022 & & 5.887 & \\
\hline Multiple R & .256 & & .169 & & .199 & & .261 & & .226 & & .149 & \\
\hline
\end{tabular}

Source: World Values Survey

Note: Table entries are unstandardized and standardized regression coefficients from OLS regressions; the values in parentheses are the standard errors of the coefficients. We used pairwise deletion of missing data. 
Figure 1. The Percent of Left and Right Extremists by National Affluence

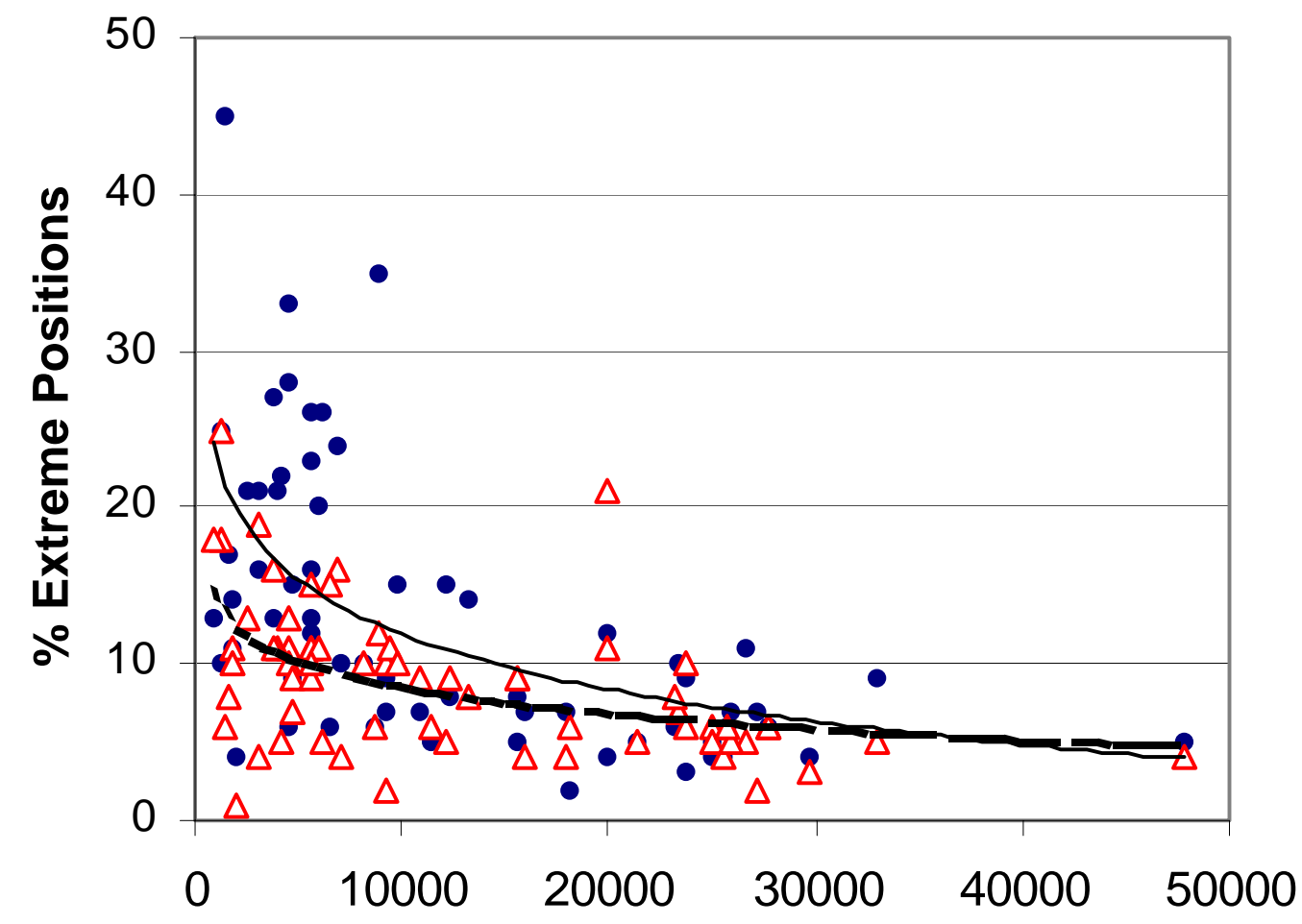

- Right $\Delta$ Left — Log. (Right) - - - - Log. (Left) 


\section{Endnotes}

1 A contrasting position questions whether publics in lower income and less developed nations were sufficiently engaged to have ideological orientations toward politics (Almond and Verba 1963; Mainwaring 1999: 131). In these societies, politics might primarily involve elite competition, since many voters are politically unaware and do not develop an ideological position.

2 Additional information on the nations included, survey methodology, questionnaires, and other technical points of the World Values Survey are available in Inglehart et al. (2004) or on the project's website: www.worldvaluessurvey.org.

3 For instance, the U.S. survey used the terms "Liberal" and "Conservative"; the Japanese survey used "progressive" versus "conservative"; Vietnam used "continuing the reform" and "no reform." The question was not asked in the surveys in China, Singapore and Egypt.

$4 \quad$ For the less developed nations in our study, a contrasting explanation suggests the causal arrow might go in the opposite direction. That is, sharp polarization in a nation may hinder national development, thus retarding economic growth and democratization.

$5 \quad$ We excluded Vietnam and Tanzania because in both instances a large majority was positioned in one category, and thus we presumed this represents a nation-specific interpretation of this scale. At the same time, since these are both low income nations, their inclusion would only strengthen the pattern in Figure 1.

$6 \quad$ The World Bank combined several indicators to "measure perceptions of the likelihood that the government in power will be destabilized or overthrown by possibly unconstitutional and/or violent means, including domestic violence and terrorism

(www.worldbank.org/wbi/governance/govdata2002/index.html). This index is strongly related to the combined percentage of Left and Right extremists in a nation ( $r=.68)$, which suggests that ideological polarization does weaken a regime.

$7 \quad$ For the combined set of nations, these four items were strongly interrelated and formed a common dimension in a factor analysis. The factor loadings were: government ownership (.70), competition is good (.62), individual responsibility (.59), income inequality (.33).

$8 \quad$ Not all nations listed in Table 1 are available on all the items we compare. Most categories are self-explanatory. The category of Asian democracies includes Japan, Taiwan, South Korea, India, the Philippines, and Turkey. For South Korea we use the 1999 data, even though there is not a separate missing data code to separate respondents not placing themselves on the scale. Turkey was included in this group to distinguish it from the non-democracies in the Middle East. Japan is included both among the advanced industrial democracies and among the Asian democracies because it reflects elements of both groups. There were a few remaining nondemocratic nations in Asia, but the number was too few to make regional generalizations.

$9 \quad$ We ran separate generational comparisons for the advanced industrial democracies. The Multiple R for these four issues predicting Left/Right orientations was slightly stronger for citizens over $50(\mathrm{R}=.25)$ than for those under $30(\mathrm{R}=.22)$. 
10 One possibility is that the low coefficient occurs because we averaged quite different relationships across the ten Latin American surveys. We examined the government ownership question as one example. Only two of these ten nations match the average correlation for advanced industrial democracies, and most display a very weak relationship. Thus, it is the absence of a relationship, rather than conflicting relationships, which primarily produces the weak overall coefficient in Latin America (-.02).

11 Because these are unstandardized regression coefficients, one can not directly compare the magnitude of effects across variables. The comparisons should focus on the same variable across regions. In judging the differences for the postmaterialism variables, the standard errors of these coefficients were in the .02-.04 range. Also see the multivariate analyses in Table 3 below.

12 For the pooled set of East European nations, materialists were 9-10 percent more common on the far Right compared to the far Left, the opposite of the relationship in Western democracies.

13 A notable exception to the pattern is the African nations, where environmental attitudes have a strong relationship (in the opposite direction to the Western democracies). We suspect this is because environmentalism is indirectly tapping economic issues because of the wording of the question.

$14 \quad$ We combined three variables--postmaterial values, environmentalism and gender equality--to predict Left/Right orientations within each region. The Multiple R in Western democracies is only half that of economic issues in these same nations.

15 We combined four questions on regime preferences, support for government by: a) strong leaders, b), experts, c), army rule, and d), support for democracy. We simply summed together responses to the four items (reversing the polarity of the democracy item) and divided the total by four. The resulting scale runs from 1) prefer non-democratic regimes and disapprove of democracy, to 4) prefer a democratic regime and disapprove of non-democratic regimes.

16 For instance, we found that both economic and religious issues were correlated with Left/Right orientations in Eastern Europe. In more detailed comparison of four Central European nations, Kitschelt et al. (1999: ch. 8) finds that religion has a strong impact in Poland, but weak effects in the other three nations. At the same time, economic issues are significant correlates of Left/Right in each nation. 